\title{
Synthesis Novel Fluorinated Cyclic Nanomeric Aza Crown Macrocyclic System Containing 1,2,4-triazine moiety and Ru-complex as Cyclin-dependent kinase 2 (CDK2) inhibitors of tumor cells (Protection of DNA Damage)-Part II
}

\author{
WAFA A. BAWAZIR and REDA M. ABDEL-RAHMAN* \\ Department of Chemistry, Faculty of Science, King Abdul Aziz University, \\ P.O.Box. 42805 Jeddah, 21551, Saudi Arabia. \\ ${ }^{*}$ Correspondig author E-mail: rm_rahman1951@yahoo.com \\ http://dx.doi.org/10.13005/ojc/360614
}

(Received: April 07, 2020; Accepted: December 06, 2020)

\begin{abstract}
Novel fluorinated 1,5-disubstituted-1,3,5-triazepine-6,7-dione (4) has been obtained from the interaction between 5,6-bis(4-fluorophenyl)-1,2,4-triazine-3-thiol (1) with 2,6-diaminopyridine 2 followed by ring closer reaction with diethyl oxalate. Also, Ru-complex 7 obtained by refluxing of compound 1 with 6-(4-fluorophenyl)-1,2,4-triazine-3,5-diamine (5) to produce compound 6 , the later was reacted with $\mathrm{RuCl}_{3} \cdot \mathrm{xH}_{2} \mathrm{O}$ to produce the target 7 . Structures of the products deduced from their elemental analysis and spectral measurements. Compounds 3, 4, 6, and $\mathbf{7}$ were evaluated as CDK2 inhibitors of tumor cells; these compounds exhibited a potential activity against CDK2, where the $\mathrm{IC}_{50}$ values were 4.5 , $6.8,4.0$, and $5.0 \mu \mathrm{M}$ respectively in comparison with Olomoucine standard $\left(\mathrm{IC}_{50}=5.0 \mu \mathrm{M}\right)$.
\end{abstract}

Keywords: Fluorinated aza-crown, Ru-complex, CDK2 inhibitors, 1,2,4-triazine, Nanomeric.

\section{INTRODUCTION}

Recently, fluorine substituted heterocyclic nitrogen systems have been incorporated into drug discovery research ${ }^{1-5}$ to improve the physicochemical properties of drugs. Also, replacing hydrogen and other functional groups with fluorinated systems can have a dramatic effect on the modulation of electronic, lipophilic and steric parameters for example, important complexes. ${ }^{6,7}$

On the other hand, during the past recent years, a variety of approaches have been taken for many classes of azathio crown macrocycles containing two 1,2,4-triazine rings as bioactive subunits to building new chemotherapy antitumor drugs. ${ }^{8,9}$ Various attempts to obtain novel lariat azathiacrown macrocycles containing tow heterocyclic rings as well their trivalent metal complexes have been reported..$^{10-13}$ Sun et al., ${ }^{14}$ prepared for a stable type of ruthenium complexes containing 3-amino-1,2,4triazino[5,6- $f] 1,10$-phenanthroline and reported their electrochemical and photophysical properties. Moreover, Abdel-Rahman et al., ${ }^{15}$ synthesized nanomeric thia-aza and aza-crown compounds and these systems exhibited excellent activity as potential

This is an Open Access article licensed under a Creative Commons license: Attribution 4.0 International (CC- BY). Published by Oriental Scientific Publishing Company @ 2018

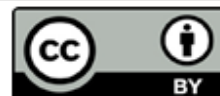


inhibitors of cyclin-dependent kinases 2 (CDK2) for tumor cells. Based on these facts, the purpose of the work is to extend the scope of our previous studies ${ }^{16,17}$ and to substitute fluorine on various 1,2,4-triazines in order to evaluate as CDK2 inhibitors of tumor cell.

\section{EXPERIMENTAL}

The chemicals were used, purchased from Fluka, Merck and Sigma-Aldrich chemical companies and used without any purification. The melting points were recorded on Stuart scientific SMP30 (Bibby, UK) melting point apparatus and reported as uncorrected. UV-Vis spectra $(\mathrm{nm})$ were recorded $(\mathrm{EtOH})$ on a Perkin-Elmer Lambda 850 spectrophotometer. FT-IR spectra were recorded on Perkin-Elmer Lambda 550 S spectrometer (ATR, v, $\mathrm{cm}^{-1}$ ). A Brucker advance DPX $400 \mathrm{MHz}$ (using TMS for ${ }^{1} \mathrm{H}$ and ${ }^{13} \mathrm{C}$ NMR as internal standards) was used for recording the ${ }^{1} \mathrm{H}(400 \mathrm{MHz})$ and ${ }^{13} \mathrm{C}(100 \mathrm{MHz})$ NMR spectra in deuterated DMSO ( $\delta$ in ppm) as a solvent. Microanalysis data $(\mathrm{C}, \mathrm{H}, \mathrm{N})$ were carried out with a Perkin Elmer 240 Q elemental analyzer. All the reactions were monitored by TLC, using silica gel coated Al plates with fluorescent indicator F254 (by using n-hexane: ethanol, 8:2). The ligand 1 was obtained from the reaction of $4,4^{`}$-difluorobenzil with thiosemicarbazide in glacial acetic acid. 6-(4Fluorophenyl)-1,2,4-triazine-3,5-diamine (5) was obtained from the reaction of aminoguanidine bicarbonate with $\alpha$-(4-fluorobenzoyl) carbonitrile in EtOH-drops piperidine. ${ }^{18}$

\section{Synthesis of N2,N6-bis(5,6-bis(4-fluorophenyl)-} 1,2,4-triazin-3-yl)pyridine-2,6-diamine (3)

A mixture of compound 1 (1.50 g, 4.98 $\mathrm{mmol}$ ) and pyridine-2,6-diamine 2 (0.27 g, 2.49 $\mathrm{mmol})$ in isopropyl alcohol $(20 \mathrm{~mL})$ was heated to reflux for $8 \mathrm{~h}$, cooled. The solid thus obtained, was filtered, washed with ethanol and recrystallized from EtOH to give 3 as yellow solid. Yield 2.24 g, 70\%. M.p: 108-110 ${ }^{\circ} \mathrm{C}$. FT-IR (ATR, v, $\mathrm{cm}^{-1}$ ): 3250 (NH), 1600 $(\mathrm{C}=\mathrm{N}), 1250$ (C-F). ${ }^{1} \mathrm{H}$ NMR (400 MHz, DMSO- $d_{6}, \delta$, ppm): 9.50, 9.30 (each s, 2NH), 8.50-8.20 $(m, 3 \mathrm{H}$, pyridine), 8.10-7.00 and 6.88-6.35 (each $m, 16 \mathrm{H}$, aromatic protons). ${ }^{13} \mathrm{C}$ NMR $\left(100 \mathrm{MHz}\right.$, DMSO- $d_{6}, \delta$, ppm): $145(\mathrm{C}-\mathrm{F}), 140(\mathrm{C}=\mathrm{N}), 110(\mathrm{C}-\mathrm{N})$. Anal. Calcd.: C, 65.32; H, 3.29; N, $19.59 \%$ for $\mathrm{C}_{35} \mathrm{H}_{21} \mathrm{~F}_{4} \mathrm{~N}_{9}$ (643). Found: C, 65.15; H, 3.06; N, 19.33\%.

\section{Synthesis of 1,5-disubsitiuted-2,5-dihydro-1H- 1,3,5-triazepine-6,7-dione (4)}

Equimolar amounts of compound 3 and diethyl oxalate in THF (20 mL) were heated to reflux for $4 \mathrm{~h}$, cooled. The solid produced, was filtered washed with ethanol and recrystallized from THF to give 4 as brown solid. Yield 1.05 g, 65\%. m.p:105$107^{\circ} \mathrm{C}$. FT-IR (ATR, v, $\left.\mathrm{cm}^{-1}\right): 1710,1708(2 \mathrm{C}=\mathrm{O})$, $1600(\mathrm{C}=\mathrm{N}), 1250(\mathrm{C}-\mathrm{F}) .{ }^{1} \mathrm{H}$ NMR $(400 \mathrm{MHz}$, DMSO$\left.d_{6}, \delta, p p m\right): 8.80-8.40(\mathrm{~m}, 3 \mathrm{H}$, of pyridine), 8.10-7.60, 7.31-6.66 (each $m$, aromatic protons). ${ }^{13} \mathrm{C}$ NMR (100 $\left.\mathrm{MHz}, \mathrm{DMSO}-d_{6}, \delta, \mathrm{ppm}\right): 160(\mathrm{C}=\mathrm{O}), 145(\mathrm{C}-\mathrm{F}), 141$ $(\mathrm{C}=\mathrm{N}), 110(\mathrm{C}-\mathrm{N})$. MS (Int. \%): $700(\mathrm{M}+3,1.15), 268$ (5.88), 214 (100), 130 (78). Anal. Calcd.: C, 63.70; $\mathrm{H}, 2.72 ; \mathrm{N}, 18.07 \%$ for $\mathrm{C}_{37} \mathrm{H}_{19} \mathrm{~F}_{4} \mathrm{~N}_{9} \mathrm{O}_{2}$ (697). Found: C, 63.59; H, 2.59; N, $17.87 \%$.

Synthesis of N3,N5-bis(5,6-bis(4-fluorophenyl)1,2,4-triazin-3-yl)-6-(4-fluorophenyl)-1,2,4triazine-3,5-diamine (6)

A mixture of compound $1(1.50 \mathrm{~g}, 4.98$ $\mathrm{mmol})$ and compound $5(0.51 \mathrm{~g}, 2.49 \mathrm{mmol})$ in DMF $(20 \mathrm{~mL})$ was heated reflux for $6 \mathrm{~h}$, cooled then poured on to ice. The solid obtained filtered washed with ethanol and recrystallized from $\mathrm{EtOH}$ to 6 as yellowish crystal. Yield $1.51 \mathrm{~g}, 82 \%$. m.p: $220-222^{\circ} \mathrm{C}$. FT-IR (ATR, $\left.v, \mathrm{~cm}^{-1}\right)$ : 3330, $3250(2 \mathrm{NH}), 1590(\mathrm{C}=\mathrm{N})$, 1250 (C-F). ${ }^{1} \mathrm{H}$ NMR (400 MHz, DMSO- $\left.d_{6}, \delta, \mathrm{ppm}\right)$ : 9.50, 9.20 (each s, 2NH), 8.60-8.45, 8.20-7.70, 7.20-6.88 (each $m, 20 \mathrm{H}$, aromatic protons). ${ }^{13} \mathrm{C}$ NMR (100 MHz, DMSO- $\left.d_{6}, \delta, p p m\right): 145(\mathrm{C}-\mathrm{F}), 140(\mathrm{C}=\mathrm{N})$, 130-127 (aromatic carbons), $110(\mathrm{C}-\mathrm{N})$. Anal. Calcd.: C, 63.33; $\mathrm{H}, 3.00 ; \mathrm{N}, 20.83 \%$ for $\mathrm{C}_{39} \mathrm{H}_{22} \mathrm{~F}_{5} \mathrm{~N}_{11}$ (739). Found: C, 63.10; H, 2.89; N, 20.72\%.

\section{Synthesis of Ru-complex (7)}

A mixture of compound 6 (1.00 g, 1.35 $\mathrm{mmol}$ ) and $\mathrm{RuCl}_{3} \cdot \mathrm{xH}_{2} \mathrm{O}(0.16 \mathrm{~g}, 0.77 \mathrm{mmol})$ in $\mathrm{N}, \mathrm{N}$ dimethylaniline $(15 \mathrm{~mL})$ was warmed in a water bath for $2 \mathrm{~h}$, cooled. The solid produced was filtered washed with methanol and recrystallized from DMF to give 7 as yellowish solid. Yield $0.56 \mathrm{~g}, 60 \%$. m.p: $>350^{\circ} \mathrm{C}$. FT-IR (ATR, v, cm ${ }^{-1}$ ): 2006 (Ru-N), 1580 $(\mathrm{C}=\mathrm{N}), 1250$ (C-F). ${ }^{1} \mathrm{H}$ NMR (400 MHz, DMSO- $d_{6}$, $\delta$, ppm): 8.80-8.44, 8.20-7.80, 7.42-7.01, 6.80-6.66 (each $m, 40 \mathrm{H}$, aromatic protons). ${ }^{13} \mathrm{C}$ NMR (100 $\left.\mathrm{MHz}, \mathrm{DMSO}-d_{6}, \delta, \mathrm{ppm}\right): 145(\mathrm{C}-\mathrm{F}), 141(\mathrm{C}=\mathrm{N})$, 132-128 (aromatic carbons), $110(\mathrm{C}-\mathrm{N})$. Anal. Calcd.: C, 59.43; H, 2.56; N, 19.55\% for Ru[C $\left.{ }_{39} \mathrm{H}_{20} \mathrm{~F}_{5} \mathrm{~N}_{11}\right]_{2}$ (1576). Found: C, 59.21; H, 2.49; N, 19.43\%.

\section{RESULTS AND DISCUSSION}

Due to the highly important of nanomeric heterocyclic systems as aza crown macrocyclic units, the presence work tends to synthesize novel fluorine substituted nanomeric aza crown bearing 1,2,4-triazines as well as their Ru-complex. 
Ashraf ${ }^{10}$ reported that the synthesis of membered macrocycles fused with two triazole ring containing nitrogen, oxygen and sulfur (as strong nucleophilic centers) inside the macrocyclic ring as donor atoms. In an attempt to produce more insight into the effect of ligand functionalization on the properties of the ruthenium (II) complex. We describe here the synthesis of cyclic aza-crown systems and their novel ruthenium (II) complexes, were these complexes depend on the nature of the ligands and there is a correlation between their spectroscopic properties and $\mathrm{Ru}$ (II)/Ru (III) redox potential. ${ }^{14}$

Fluorine substituted aza-crown system 4 has been obtained from the reaction of 5,6-di(4 fluorophenyl)-1,2,4-triazin-3-thion (1) with 2,6diamino pyridine (2) in refluxed isopropyl alcohol to give 2,6-diheteroaryl aminopyridine 3. Ring closure reaction of $\mathbf{3}$ with diethyl oxalate in boiling THF led to the direct formation of 4 (Scheme 1). The FT-IR spectrum of $\mathbf{4}$ was recorded the presence of carbonyl group $1700 \mathrm{~cm}^{-1}$ with lack of tow $\mathrm{NH}$ groups also exhibited a vibrational band at $1250 \mathrm{~cm}^{-1}$ for the presence of C-F. The ${ }^{1} \mathrm{H}$ NMR spectrum was not showed any resonated signals above $8.80 \mathrm{ppm}$. Additionally the ${ }^{13} \mathrm{C}$ NMR spectrum was showed resonated signals at $0180-160 \mathrm{ppm}$ of two $\mathrm{C}=\mathrm{O}$ carbons and $140 \mathrm{ppm}$ for carbon-fluorine.

The interaction between 5,6-di(4'fluorophenyl)-3-mercapto-1,2,4-triazine (1) with 3,5-diamino-6-(4 -fluorophenyl)-1,2,4-triazine (2) (by $2: 1 \mathrm{~mol}$ ) in refluxing DMF afforded $\mathrm{N}^{3}, \mathrm{~N}^{5}$ bis(5,6-bis(4-fluorophenyl)-1,2,4-triazin-3-yl)-6(4-fluorophenyl)-1,2,4-triazine-3,5-diamine (6) (Scheme 2). It is interesting that the treatment of two-equivalent amounts of compound 6 with $\mathrm{RuCl}_{3}$. $\mathrm{xH}_{2} \mathrm{O}$ in warming $\mathrm{N}$-dimethylaniline, gave a new type of complex 7 (Scheme 2).

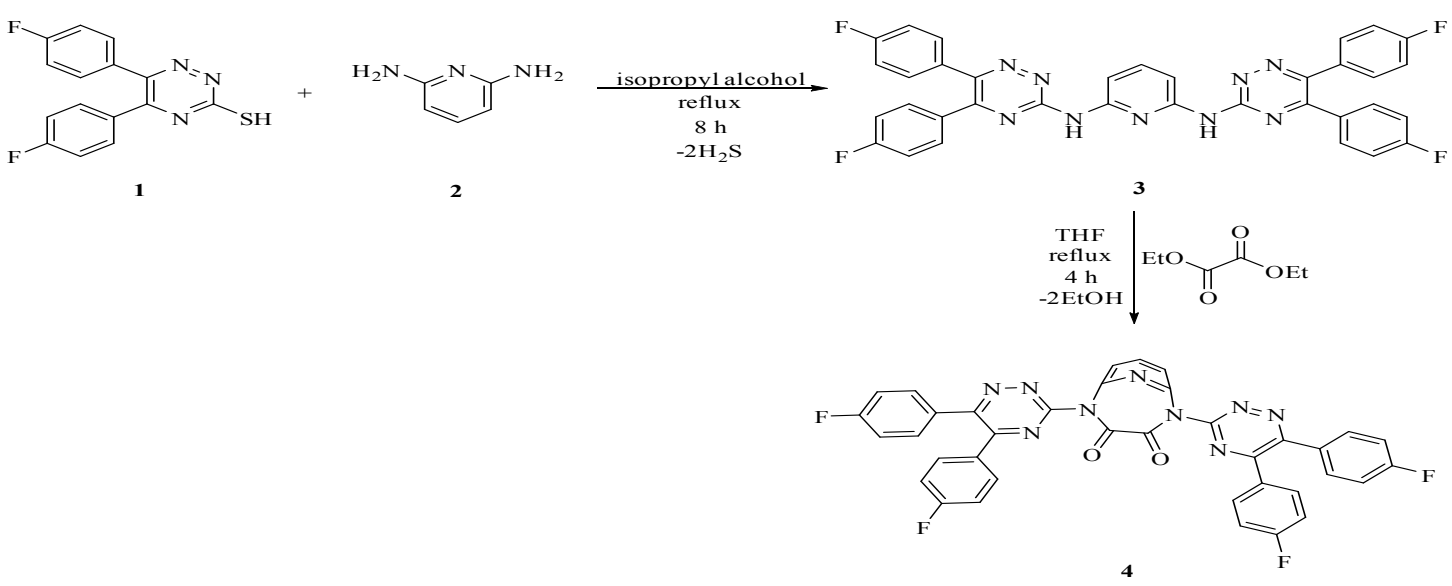

Scheme 1. Synthesis of compounds 3-4

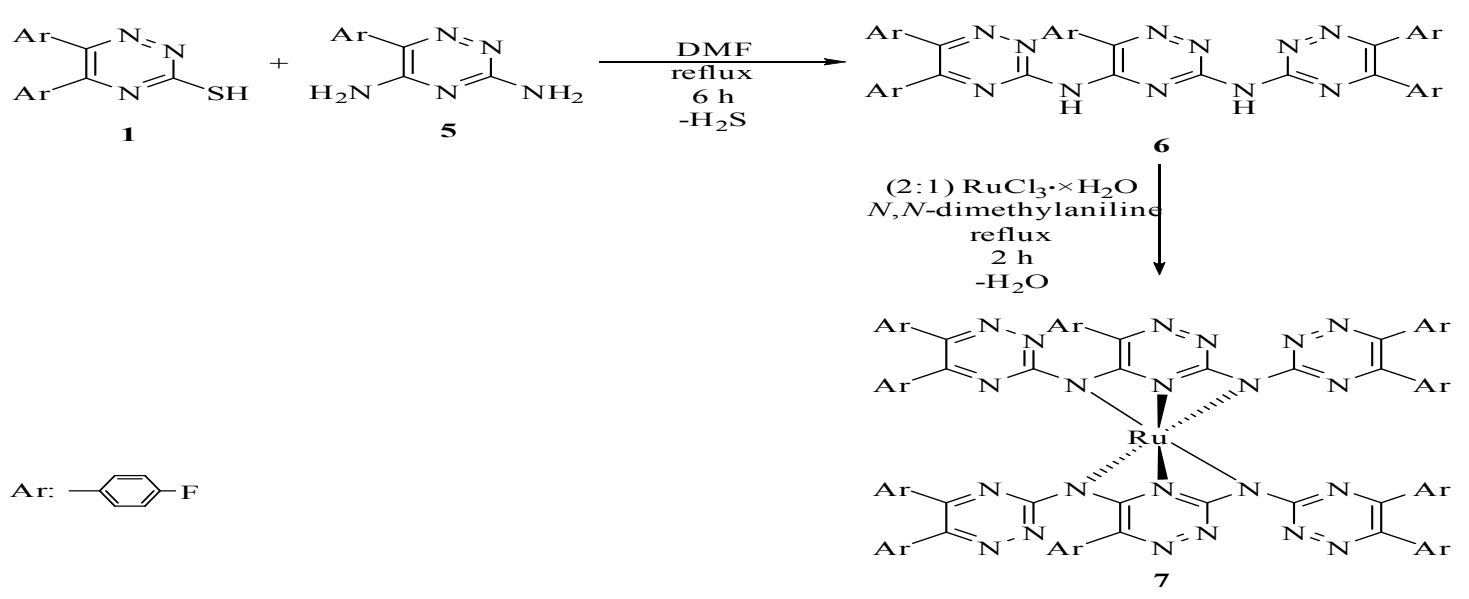


The FT-IR spectrum of compound 6 was recorded vibrational bands of $\mathrm{NH}$ groups at 3330 , $3250 \mathrm{~cm}^{-1}$, while compound 7 showed a lack of $\mathrm{NH}$ functional groups. FT-IR spectra of both 5 and 6 exhibited $v$ at $1250 \mathrm{~cm}^{-1}$ for C-F presence. On the other hand the ${ }^{1} \mathrm{H}$ NMR spectrum of 6 showed only resonated signals at $\delta 8.9$ and $8.5 \mathrm{ppm}$ attribute to $\mathrm{NH}$ protons of amino-1,2,4-triazines. Also, that of 7 showed a lack of $\mathrm{NH}$, which confirmed that metalcomplex formed. ${ }^{1} \mathrm{H}$ NMR spectrum of 7 was showed a slight downfield in comparison to free ligand 6 as a result of coordination to the metal Ru ion, which acts as an electron acceptor from the heteroatoms $(\mathrm{N})$ of ligand to Ru. The UV absorption of Ru-complex 7 was showed a band at 2000-380 $\mathrm{nm}$ was attributed to intraligand $\left(\pi-\pi^{\star}\right)$ transition, while that at $>400 \mathrm{~nm}$ assigned to metal-ligand charge-transfer transition. Besides, magnetic measurements and electronic spectra of Ru-complex 7 formed in the range 4.00 4.25 BM at room temperature, which confirmed that structure.

Finally, the mass spectral study of compound 4 showed the molecular ion and the base peak at 700 and $214 \mathrm{~m} / \mathrm{z}$, respectively, which established the stability and the structural formula.

\section{The Cyclin-dependent kinase 2 inhibition activity}

Fluorine incorporation on key positions plays a significant role in altering the physicochemical and biological characteristics of organic chemistry. Thus, fluorine increases binding affinity, reduces plasma protein binding leading to a higher free fraction of the drug and increases cell penetration. ${ }^{19}$ Based on these valuable observations, and in part of our containing efforts in drug development, the present work describes an attempt towards the synthesis of fluorine substituted cyclic nanomeric aza-oxo crown macrocyclic and their Ru-complexes systems as Cyclin-dependent kinase 2 inhibition of tumor cells.

Additionally, the cancer diagnoses research drug resistance is one of the most significant difficulties that cause failure in tumor treatment, a recurrence of the disease, or even the death of a patient. Thus, the development of new medication continuous to offer hope to prohibit the resistance capabilities of the tumor cell lines..$^{20-22}$ One of the attempts to control the tumor cells, is Cyclin-dependent-kinases 2 evaluations.

The new fluorinated aza-oxo systems and their Ru-complexes have been evaluated to inhibit the activity of Cyclin-dependent kinase 2 in a biochemical assay. The inhibitory concentration $\left(\mathrm{IC}_{50}\right)$ values were obtained according to the reported method. ${ }^{23,24}$ Olomoucine used as a standard, and the results data reported in Table 1.

The results obtained reveal that compounds 7, 6, 3, and 4 show very significant CDK2 inhibitory activity. Compound 7 found to be active such as Olomoucine $\left(\mathrm{IC}_{50}=5.0 \mu \mathrm{M}\right)$, while the other tested compounds less activity than the standard compound $\left(\mathrm{IC}_{50}=4.0-6.8 \mu \mathrm{M}\right)$.

\begin{tabular}{cc}
$\begin{array}{c}\text { Table 1: Cyclin-dependent } \\
\text { kinase } 2 \text { inhibiting activity of } \\
\text { fluorinated compounds } 3-7\end{array}$ \\
\hline Compounds & $\mathrm{IC}_{50} \pm \mathrm{SD}(\mu \mathrm{M})^{\star}$ \\
\hline $\mathbf{3}$ & $4.5 \pm 2.5$ \\
$\mathbf{4}$ & $6.8 \pm 1.0$ \\
$\mathbf{6}$ & $4.0 \pm 2.8$ \\
$\mathbf{7}$ & $5.0 \pm 1.7$ \\
Olomoucine & $5.0 \pm 1.0$ \\
\hline
\end{tabular}

\section{CONCLUSION}

Simple methods to obtain fluorine substituted cyclic nanomeric aza-oxo crown macrocyclic systems bearing 1,2,4-triazine moiety have been reported, and stable Ru-complexes, also produced. Cyclin-dependent kinase 2 inhibitors of tumor cells also investigated, were the Ru-complex 7 showed potential inhibitory activity as the reference standard. This work is required in order to explore the scope and limitation of its biocidal effects.

\section{ACKNOWLEDGMENT}

This project mainly funded by Deanship of Scientific Research (DSR), King Abdulaziz University, Jeddah, Saudi Arabia, under Grant Number: 197-130-1439. The authors, therefore, acknowledge with thanks to DSR technical and financial support.

\section{Conflicts of Interest}

The authors declare no conflict of interest. 


\section{REFERENCES}

1. Makki, M. S. T.; Bakhotmah, D. A.; AbdelRahman, R. M.; El-Shahawy, M. S., Designing and synthesis of new fluorine substituted pyrimidine-thion-5-carbonitriles and the related derivatives as photochemical probe agents for inhibition of Vitiligo disease. Int. J. Org. Chem., 2012, 2(3), 311-320.

2. Abdel-Rahman, R. M.; Makki, M. S. T.; Bawazir, W. A., Synthesis of some more fluorine heterocyclic nitrogen systems derived from sulfa drugs as photochemical probe agents for inhibition of Vitiligo disease-part I. J. Chem., 2011, 8(1), 405-414.

3. Abdel-Rahman, R. M.; Makki, M.S.T.; Bawazir, W. A. B., Synthesis of fluorine heterocyclic nitrogen systems derived from sulfa drugs as photochemical probe agents for inhibition of Vitiligo disease-part II. J. Chem., 2010, 7 (S1), S93-S102.

4. Abdel-Rahman, R. M., Synthesis, and chemistry of fluorine-containing bioactive 1,2,4-triazines--an overview. Chemistry of uncondensed 1,2,4-triazines-part III. Pharmazie., 1999, 54(11), 791-803.

5. Filler, R.; Saha, R., Fluorine in medicinal chemistry: a century of progress and a 60year retrospective of selected highlights. Future Med. Chem., 2009, 1(5), 777-91.

6. Ramadan, A. A.; Abdel-Rahman, R. M.; Seada, M. H., Studies on complexes of Cu(II), $\mathrm{Ni}(\mathrm{II}), \mathrm{Co}(\mathrm{II})$ and $\operatorname{Ln}(\mathrm{III})$ with $3-(\alpha$-benzoyl) benzylidenehydrazino-5,6-diphenyl-1,2,4triazine. Asian J. Chem., 1992, 4(3), 569-578.

7. Ramadan, A. T.; Abdel-Rahman, R. M.; ElBehairy, M. A.; Ismail A., Thermodynamics of complexation of transition and Lanthanide ions by 3-( $\alpha$-carboxymethylaminobenzylidene hydrazino)-5,6-diphenyl-1,2,4-triazine. Thermochim. Acta., 1993, 222, 291-303.

8. Sridhar, S. K.; Saravanan, M.; Ramesh, A., Synthesis and antibacterial screening of hydrazones, Schiff, and Mannich bases of isatin derivatives. Eur. J. Med. Chem., 2001, 36(7), 615-625.

9. Singh, K.; Barwa, M. S.; Tyagi, P., Synthesis, characterization and biological studies of Co (II), $\mathrm{Ni}$ (II), Cu (II) and Zn (II) complexes with bidentate Schiff bases derived by heterocyclic ketone. Eur. J. Med. Chem., 2006, 41(1), 147-153.

10. Abbas, A. A., Synthesis of novel lariat azathia crown macrocycles containing two triazole rings and bis crown macrocycles containing four triazole rings. Tetrahedron., 2004, 60(7), 1541-1548.

11. Vandna, S.; Upma, S., Synthesis and spectroscopic studies of Schiff base and its divalent and trivalent metal complexes. Asian J. Chem., 2013, 25(14), 8195-8198.

12. Suresh, M. S.; Padmanabhan, M., Synthesis, and characterization of axially linked heteroleptic polymeric and monomeric Lewis base adducts of bis-(2-mercaptobenzothiazolato) Nickel (II) and its extraordinary thermal decomposition. Asian J. Chem., 2013, 25(14), 7669-7674.

13. Foroughifar, N.; Mobinikhaledi, A.; Ebrahimi, S.; Moghanian, H.; Fard, M. A. B.; Kalhor, M., Synthesis of a new class of azathia crown macrocycles containing two 1,2,4-triazole or two 1,3,4-thiadiazole rings as subunits. Tetrahedron Lett., 2009, 50(7), 836-839.

14. Sun, B.; Chu, J.; Chen, Y.; Gao, F.; Ji, L.-N.; Chao, H., Synthesis, characterization, electrochemical and photophysical properties of ruthenium(II) complexes containing 3-amino1,2,4-triazino[5,6-f]-1,10-phenanthroline. J. Mol. Struct., 2008, 890(1), 203-208.

15. Abdel-Rahman, R. M.; Makki, M. S. T.; Bawazir, W. A.; Alharbi, A. S., Synthesis of some new nanomeric thia-aza and aza-crown macrocyclic systems bearing 1,2,4-triazinone moiety as inhibitors of cyclin-dependent kinases 2: Part-I. Indian J. Heterocycl. Chem., 2020, 30(2), 249-257.

16. Makki, M. S. T.; Abdel-Rahman, R. M.; ElShahawi, M. S., Synthesis and voltammetric study of some new macrocyclic sulfur compounds for use as chelating agents for separation of arsenic (III) in wastewater and as molluscicidal agents against Biomophalaria Alexandrina Snails. C. R. Chim., 2012, 15(7), 617-626. 
17. Makki, M. S. T.; Abdel-Rahman, R. M.; ElShahawi, M. S., Voltammetric behavior, biocidal effect and synthesis of some new nanomeric fused cyclic thiosemicarbazones and their mercuric (II) salts. Arab. J. Chem., 2014, 7(5), 793-799.

18. Makki, M. S. T.; Bakhotmah, D. A.; AbdelRahman, R. M.; Aqlan, F. M., New route to synthesize fluorine substituted Lamotrigine drug analogs as an anti-inflammatory agent. Curr. Org. Synth., 2018, 15(1), 116-125.

19. Sandford, G., Elemental fluorine in organic chemistry (1997-2006). J. Fluor. Chem., 2007, 128(2), 90-104.

20. Goss, G. D.; Tsvetkova, E., Drug resistance and its significance for treatment decisions in non-small-cell lung cancer. Curr. Oncol., 2012, 19, S45-S51.

21. Maeda, H.; Khatami, M., Analyses of repeated failures in cancer therapy for solid tumors: poor tumor-selective drug delivery, low therapeutic efficacy, and unsustainable costs. Clin. Transl. Med., 2018, 7(1), 1-20.

22. Zahreddine, H.; Borden, K., Mechanisms, and insights into drug resistance in cancer. Front. Pharmacol., 2013, 4(28), 1-8.

23. Kryštof, V.; Cankar, P.; Fryšová, I.; Slouka, J.; Kontopidis, G.; Džubák, P.; Hajdúch, M.; Srovnal, J.; de Azevedo, W. F.; Orság, M.; Paprskárová, M.; Rolcík, J.; Látr, A.; Fischer, P. M.; Strnad, M., 4-Arylazo-3,5-diamino-1Hpyrazole CDK inhibitors: SAR study, crystal structure in complex with CDK2, selectivity, and cellular effects. J. Med. Chem., 2006, 49 (22), 6500-6509.

24. Gucký, T.; Reznícková, E.; Džubák, P.; Hajdúch, M.; Kryštof, V., Synthesis and anticancer activity of some 1,5-diaryl-3(3,4,5-trihydroxyphenyl)-1H-pyrazolo[4,3-e] $[1,2,4]$ triazines. Monatsh. Chem., 2010, 141(6), 709-714. 